\title{
Designing and building of training model and platform for service outsourcing talents based on CDIO
}

\author{
Zhang Liang \\ Hangzhou Institute of Service Engineering \\ Hangzhou Normal University \\ Hangzhou, China, 310017 \\ zhl@hznu.edu.cn
}

\author{
Li Yinru \\ Hangzhou Institute of Service Engineering \\ Hangzhou Normal University \\ Hangzhou, China, 310017 \\ liyinru123@163.com
}

\begin{abstract}
The service outsourcing industry is developing rapidly in the context of the government to adjust the industrial structure and change the economic development mode. While, service outsourcing talents of China emerge of a large gap to meet the need of service outsourcing industry. On the basis of CDIO engineering education theory, our school cultivates middle or advanced service outsourcing talents. In this process, on the basis of training philosophy which is application-oriented, internationalized and personalized, our school persists in "Four in One" running schools pattern which united all powers from government, enterprises, training institutions and schools. As well as we focused on the development of students capacities that included rudimentary knowledge, professional skills, applied foreign languages, comprehensive quality and engineering ability. As a result, a training model of middle or advanced service outsourcing talents is explored which combined teaching of basic knowledge with training of practical capability.
\end{abstract}

Key Words- Talents of Service Outsourcing; Model of Cultivation; Platform of Cultivation; CDIO

\section{INTRODUCTION}

Talents' Cultivation of the service outsourcing not only conform to the demands of China's industrial structure adjustment, but also accord with the demands of model reforms of the computer professional talents. At recent years, the pace of structural adjustment and echelon transfer become faster than before in the world information industry. Following the manufacturing industry, the service outsourcing industry set off a second wave of industrial transfer on a global scale. This is an opportunity for many countries which including China to speed up the process of industrial internationalization and enhance their comprehensive competitiveness. Therefore, China vigorously develops the service outsourcing industry to achieve industrial restructuring and transform the mode of economic growth. At the same time, China's service outsourcing industry has got the strong support in national policies from China's government. And now, the top priority is to speed up the process that cultivating the service outsourcing talents. However, most of our computer talents trained by the traditional engineering education mode cannot meet the current service outsourcing industry demands for talents. Because they just pay attention to knowledge learning and are lack of the practice ability and engineering capabilities. To adapt the needs of the service outsourcing industry for talents, we will reform the training mode of computer talents.

\section{OVERVIEW OF SERVICE OUtSOURCING AND THE CURRENT STATUS OF THE DEMANDS FOR SERVICE OUTSOURCING TALENTS}

\section{A. Overview of Service Outsourcing}

Service outsourcing is an activity that the enterprise peeled off the basic, common and non-core IT business and business process which originally provided by themselves, and outsourced it to the professional service provider outside the enterprise to accomplish. As in [1], Charles l.Gay and Jame Essinger proposed a definition of the service outsourcing that is the enterprise shift the ongoing management responsibility of a service to a third party according their agreement about the service. It is a management model to improve organizational efficiency and a running model to reduce operating costs. In the international service outsourcing market, most of enterprises from developed countries are outsourcers. In all of the outsourcers, enterprises of United States account for about two thirds, and enterprises of European Union and Japan account for about one third. However, most of the service providers are always the enterprises from developing countries. For example, India that has more than 60 percent market share is the most important service provider in Asia followed by China and ASEAN. At present, the US market is monopolized by India and Philippines, and the European market is monopolized by Ireland, Israel and the Czech Republic. And the Japan and South Korea markets are monopolized by China.

\section{B. The Current Status of the Demand for Service Outsourcing Talents}

The huge market demand of service outsourcing talents has great significance to the employment of college graduates. In recent years, the global outsourcing industry is developing rapidly. Researches show that the rate of information technology outsourcing (ITO) grown from 5 percentage in 2006 to 7 percentage in 2011. The revenue of the global outsourcing market in 2020 is expected to be more than 150 trillion Yuan. Accordingly, we can see a huge development potential about the industry. With the two 
times growth of service outsourcing business, the bases and enterprises of service outsourcing have mushroomed developed. Nowadays, this industry has become an important force to pull the employment of university students.

Most colleges and universities of China focused on the learning of theoretical knowledge, and underestimate the practical ability and project capability. Therefore, there exists a gap between the enterprise demands for their employee and the actual abilities of the students in the practical ability and project capability. It lead to the graduates are not competent to the work of enterprises until they have be trained by external training institutions or a long time internal practice. This affects the rapid development of China's service outsourcing industry. Therefore, we need to reform the training model of service outsourcing talents according to the CDIO theory.

\section{Introduction about CDIO}

Reference [2] was proposed that CDIO, the new concept and system of engineering education, was developed collectively by the Massachusetts Institute of Technology of USA, Chalmers University of Technology, Linkoping University and the Royal Institute of Technology of Sweden in 2001. Actually, it is composed by the first letter of four words which are Conceive, Design, Implement and Operate. CDIO emphatically emphasize on cultivating students with four abilities which are technical knowledge and reasoning, personal and professional skills, interpersonal skills, and conceiving, designing, implementing and operating systems under the completely project development cycle as the background.

In the CDIO system, "Conceiving" means that formulating the analysis program of customer needs, technical program and business plan. "Designing" represents a stage that the system functions to achieve described by drawing design, project design et al. "Implementing" means that achieving the system functions described in the design stage through the hardware components combine with software coding. "Operating" refers to make the system or product of implementing stage completed into use, and improve the performance of this system or products [3].

\section{THE TRAINING MODEL OF SERVICE OUTSOURCING TALENTS}

There are four major of service outsourcing talents which are Computer Science and Technology, Software Engineering, Information and Computing Science (Orientation to Financial Service), Electronic Information Engineering (Orientation to Embed) in Hangzhou Normal University. Cultivating ITO talents and BPO talents is the main goal of the university. In order to integrate the efforts of the various parties to develop the service outsourcing talents, the university created the "four in one" school system. And after analyzed the market demands for service outsourcing talents, the university has determined a certain training goals and contents of talents which stressed theoretical knowledge as well as practical experiences.
Diversified school-enterprise cooperation mode and various resources platform will provide a solid foundation to training the talents of service outsourcing industry.

\section{A. The "four in one" running schools pattern}

In the process of cultivating the professional talents that meet the development needs of the service outsourcing industry, the government departments play a guiding and coordinating role for the cooperation of schools and enterprises. The enterprises clearly understand the market demands, and they play a dominant role that providing training venues and internship positions for undergraduates. The service outsourcing training institutions have mature management system and relevant experiences. All of these resources should be used for cultivating talents. Consequently, HZNU achieve a "four in one" model which make the strengths and resources of government departments, enterprises, training institutions and schools fused in together.

Because of the "four in one" model closely connect with the needs of market-oriented; the graduates have higher market competitiveness. And the enterprises, schools, governments and training institutions will get corresponding interests through the "four in one" model.

For enterprises, the students with professional skills and abilities can quickly adapt to the corporate environment, and participate in the project or program development. The interns' salary will be less than full-time staff's. In some degree, it will reduce the company's financial pressure. The excellent interns will become excellent employees, and they will develop outstanding products or program. From this perspective, enterprises can also reduce the costs for product testing and maintenance.

For schools, cultivating students according to the enterprises needs not only solved the contradictions that engineering education separated with practice, but also avoided the embarrassment that the graduates are difficult employed by company. This is a way to improve schools ranked.

For government, cultivating the high quality talents that met the business needs will enhance the confidence of the outsourcer countries to China's quality of service outsourcing, and win the favor of outsourcer countries. Finally, it will adjust China's industrial structure, and transform the model of economic development, and enhance China's international image in the global world [4].

Participating in the "four in one" model, training institutions can not only get the tax concessions from government, but also can improve their own reputations in the market. In some degree, it will enhance competitiveness of the training institutions in the future market.

\section{B. Training goals and contents of the talents}

To master the employees' current situation of service outsourcing enterprises and demands of the future employees, HZNU conducts a research focusing on the top 10 enterprises in Hangzhou service outsourcing industry. In the process, they make a typicality research to senior managers and senior technical staffs in the service 
outsourcing enterprises, and make a sample survey to small-sized and medium-sized service outsourcing enterprises. And an expert guidance commission that make the top-level design to cultivating the talents have composed by experts and scholars from government, enterprises, training institutions and schools in 2009. The commission takes a theoretical discussion and guidance for service outsourcing field from discipline construction, teaching reform, personnel training, social training and industry study.

On this basis, combined with itself basic situation, the school sets the goals of talents with basic knowledge, professional capabilities, applied foreign languages, comprehensive qualities and engineering capabilities.

Modern engineering systems increasingly rely on multi-disciplinary background knowledge, so that the abundant engineering theories and professional knowledge become the things that engineering students must mastered. Service outsourcing is a practical engineering. Engineering students have to be qualified professional skills such as project development and related document writing. According to the current situation of China's service outsourcing industry, mainly outsourcer countries are Europe, the United States, Japan and South Korea. In order to well communicate with these outsourcers, the employees of service provider should have very well communicating ability in foreign language. Therefore, the training of service outsource talents should emphasis on the development of students' foreign language skills. Comprehensive qualities represent that the students' professionalism, interpersonal skills, social responsibility, etc. All of these needs to be focused when the school cultivates engineering students of service outsource. Meanwhile, in order to preferably adapt the corporate environment the students must understand the corporate culture and improve their own qualities as well as interpersonal skills and communication skills. Finally, the ability that conceiving, designing, implementing and operating system or product from corporate and social level is necessary for engineering students to really achieve the system or product[3]. It is also a ability, "engineering capabilities", stressed by CDIO engineering education philosophy.

\section{Curriculum Knowledge System and Engineering Practical Stage}

In the teaching process, we not only adhere to teach the knowledge of service outsourcing, but also focus on the training of practical ability. Knowledge of subject can be a basis to the training of the practical ability. At the same time, subject knowledge can be deeply understand, mastered and applied through practical experiences. When the curriculum knowledge and practical skills form a benign circulation, the students will get more and more knowledge, and enhance their practical abilities. The relationship between curriculum knowledge system and practice stage showed in Fig. 1.

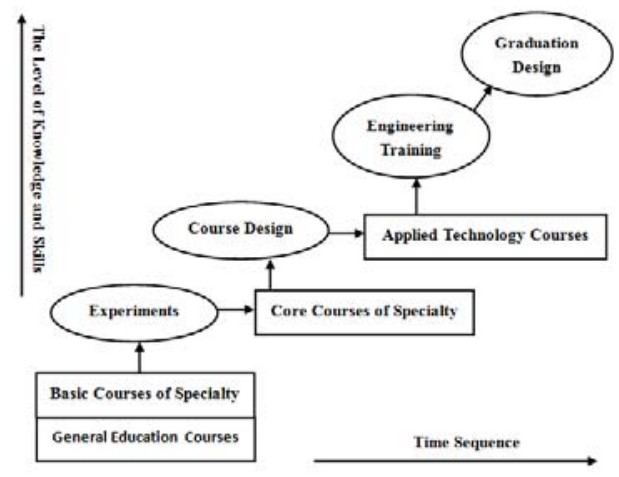

Figure 1. The relationship between curriculum knowledge system and practice stage

The course is divided into four categories, respectively general education course, basic courses of specialty, core courses of specialty and applied technology courses. The first three classes are aimed to improve the depth of professional knowledge, and the last one is making the learned knowledge used in practice in order to improve students' practical ability. Freshman and sophomore mainly learn the general education class and basic courses of specialty. And the junior and senior students mainly learn the core courses of specialty and applied their learned technology.

General education course are composed by two parts. One part is obligatory classes such as college English class, higher mathematics class, and the other is optional classes which are aimed to enhance students' the sense of social responsibility, occupational ethics etc before these students become a employee.

Basic courses of specialty represent several courses that did not require others courses as precursors for students to learning. Most of these courses are introductory course. For example, the courses, such as Introduction to Computer Science, Introductory Circuits for Electrical and Computer Engineering, are the basic courses to the major of Computer Science and Technology.

Core courses of specialty required a lot of professional knowledge as fundament compared with the basic courses of specialty. Such courses are involved to the deep level of knowledge, and are often going to be learning after the students learned the basic courses of specialty.

Applied technology courses are a kind of practical course. If the students want to master the technology of these courses, they need have more practical experiences. Then the comprehensive projects and programs in these courses will be good driver to improve the students' practical ability. J2EE and C\# are some applied technology courses in the major of Computer Science and Technology.

There are four practical stages which are experiments, course design, engineering training and graduation respectively, design to develop the students' practical ability.

Experiments can be set up in one kind course. But a course may have many experiments. In the practical stage, experiments belong to a verified practical stage which is 
always arranged in class.

A course may have one or more course designs which focused on applying the core technology of the course. The course design always starts at the end of course when the students have completely learned the knowledge of this course. In organizational form, a group of several students cooperate to accomplish the course design.

The stage of engineering training aimed to enhance the students' engineering ability under the background of enterprises. Students will undertake the project's conceiving, designing, implementing and operating in the environment that simulate the enterprises' organization structure, business processes, management mechanism. All cases that the students undertaken are the real projects of enterprises. At this stage, the project manager of enterprises will be prime tutor to conduct students' learning, and the teachers of schools will be the vice tutor.

The last stage is graduation design. At this stage, students can participate in a project of the corporation as a internship to improve their professional skills. They can do their graduated design combined with the project of corporation. Meanwhile, they can also get the guidance from school teachers on thesis writing.

\section{Diversified school-enterprise cooperation models}

To adapt the different training needs of differential level talents, the corporation models between schools and enterprises are various. Diversified school-enterprise cooperation models have three kinds: the mode of enterprise full participation, the mode of enterprise segmented participation and the mode of enterprises embedding featured courses.

1) The Mode of Enterprise Full Participation.

The enterprises will fully participate in the cultivation of talents from formulation of the training program, admissions consulting and publicity, new students' beginning education organization, management, guidance and teaching of daily curriculum. This mode with its rich experience of operating company brings students and trainees closely to the real business environment. In this environment, students will completely participate in the developing process of several business projects.

\section{2) The Mode of Enterprise Segmented Participation.}

When students mainly accomplished general education course, basic and core courses, the enterprise started to involve each teaching steps. The enterprise imports the professional feature courses for students, and dominants students' learning on job. Meanwhile, the system of professional tutor is set up. The professional tutors who are always the member of project managers in enterprise guide students' learning at any time. Skills training and research about project for students regularly carried out by the professional tutor.

\section{3) The Mode of Enterprises Embed Featured Course}

In order to make the graduates meet the demands of company positions as soon as possible, the enterprises embedded featured courses, such as specialized English, practice to software development process and practice to comprehensive development of project, at different stage of teaching process.

\section{The Construction of Training PlatForm to SERVICE OUTSOURCING TALENTS}

Enterprises, government and schools build the training platform to service outsourcing talents together. In order to cultivate the talents met the demands of enterprises; our school has established a partnership with Microsoft, Cisco and other companies. Training platform that constructed by schools and enterprises, such as IBM Software Engineering Training Lab and Renesas Embedded Training Lab, provide a strong support for cultivating the practical ability of Service Outsourcing talents. The enterprises clearly understand the market demands, and they should play dominant roles that provide training venues and internship positions for undergraduates. Meanwhile, our school gets the support from project of National Service Outsourcing Engineering Training Center, project of Model Outsourcing City of Public Service Platform Construction as well as project of Provincial Training Platform.

To construct of guidance and communication platform for talents training, an expert guidance commission was established by experts and scholars from government, enterprises, training institutions and schools. The commission takes a theoretical discussion and guidance for service outsourcing field from discipline construction, teaching reform, personnel training, and social training to industry study. In addition, our school also organized the Committee, Forum, Training Union and other institutions to guide the cultivation of Service Outsourcing talents. Moreover, our school also actively participates in conferences and forums at home and abroad to absorb the advanced thoughts and ideas of engineering education. As a pioneer, our school of training the talents of service outsourcing, the school continues to improve their philosophy and mode of talents' cultivation.

\section{CONCLUSION}

On the basis of CDIO engineering philosophy, our school reforms the model of talents cultivation according to China's fundamental realities and the school's idea of talents cultivation. Our school is open to collaboration with enterprises, and gets the various resources together to cultivate excellent talents that fit the market demands. Eventually, the practice of reform proved that this training model is feasible. The students training by this model have greatly increased in professional skills, communication skills and engineering ability. The students have outstanding performances in the national service outsourcing competition and provincial service outsourcing competition. All of these verified that this model is worth to use for reference. Therefore, we will keep on working hard to reform the education deeply and continue to cultivate the excellent students.

\section{REFERENCES}

[1] Gay C.L., Essinger J. Inside outsourcing: The insider's guide to managing strategic sourcing. London: Nicholas Brealey Publishing, 2000 . 
[2] Edward F.C., Johan M., William A.L et al. The CDIO Syllabus v2.0. In: Proceedings of the 7th International CDIO Conference. Copenhsagen: Technical University of Denmark, pp. 20-23, June 2011.

[3] WANG Shuo-wang, HONG Chen-wen. CDIO: the Classic Mode of Engineering Education in MIT. Journal of Higher Education in Science \& Technology, Vol. 28, pp. 116-117, 2009.

[4] Yanqing Wang, Zhongying Qi, Ziru Li et al. Institute-industry interoperation model: an industry-oriented engineering education strategy in China. Asia Pacific Educ, Vol.12, pp. 665-674, 2011.

[5] LI Hong-mei, ZHANG Hong-yan, CHEN Xu-dong. Research on Practical Teaching in Software Engineering Based On CDIO. Higher Education of Sciences, issue.3, pp. 97, 2011. 